\title{
Exploring Professional Development from Brief Experiences: Case Studies of Secondary EFL Teachers in China
}

\author{
Yuan Qingling ${ }^{1}$, Yuan Qunhua $^{2} \&$ Wan Ying ${ }^{1}$ \\ ${ }^{1}$ Yichun High School, Yichun, Jiangxi, China \\ ${ }^{2}$ Guangdong University of Foreign Studies, China \\ Correspondence: Yuan Qunhua, School of Economics \& Trade, Guangdong University of Foreign Studies, \\ Guangzhou, Guangdong, China. Tel: 86-136-4021-3337. E-mail: yqh15@126.com
}

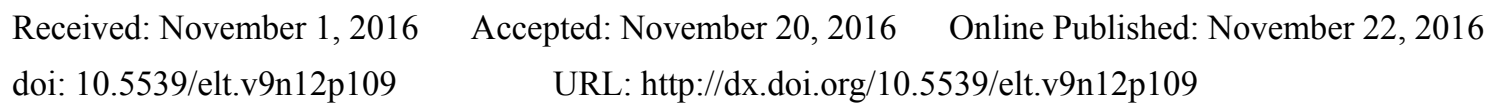

\begin{abstract}
The current situation of educational reforms since 1990s has brought up a booming demand of competent EFL teachers because of economic globalization and further opening-up policy in China. So it's vital and significant to explore EFL teachers' professional development in order to promote English language teaching. Based on the Constructivism Perspective in educational psychology and new trends in Second Language Teacher Education, this research focuses on six secondary EFL teachers' critical incidents and narrates their brief experiences by deep interview and field notes. After categorized analysis through recurring themes, the discussions about four domains (i.e. learning experiences, knowledge \& beliefs, teaching practice and social context) are summarized below. These teachers have experienced pre-service $\&$ in-service and formal $\&$ informal learning that has different features. Secondly, they hold some common knowledge \& beliefs, which are always developing but fluctuate with realities. Next, their language teaching develops from initial to survival then to mastery and personalization, but each stage is distinctive in different situations. Social context facilitates or constrains their professional development, but their responses to it are various to seek personal and professional balance. In conclusion, it interprets five interactive factors in the process of teacher professional development: Normal education and professional programs play essential roles; Self-directed teaching \& school-based activities provide diverse paths; Perfection of language \& teaching serves as peculiar professional qualities; Love for students \& love for teaching functions as original driving force; Chinese social context works as potential external stimuli. Finally, it presents some feasible suggestions.
\end{abstract}

Keywords: teacher professional development, secondary EFL teachers, learning experiences, knowledge \& beliefs, teaching practice, social context

\section{Introduction}

\subsection{Research Background}

As the executives of educational reforms, teachers directly relate to the enforcement of advanced concepts and finally change the world of school by understanding it. It is due to teachers' importance to school improvement and education promotion that the researches about teacher education and professional development have become a hot issue in general education since 1980s and in second language teacher education since 1990s.

In China, English as a foreign language (EFL) has been a core subject of NCEE (National College Entrance Examination) since 1978. After several syllabus reforms between 1980s and 1990s, a new national English curriculum for basic education has been experimented, revised, popularized and re-revised since 2001. Now the newest revised edition (MOE, 2012) is put into use. Consequently, the past decades have witnessed many significant achievements except for some problems such as inadequately trained and skilled teachers (Nunan, 2003). Therefore it sparks the idea of exploring how EFL teachers learn to teach through their careers in the context of Chinese educational reforms.

\subsection{Literature Review}

Fullan defines teachers' professional development as the sum total of formal and informal learning experiences throughout one's career from pre-service teacher education to retirement (Fullan \& Stiegelbauer, 1991). In this regard, teacher professional development is by and large learning. Drawn from Piaget and Vygotsky's viewpoints 
of constructivism, teacher learning is an internal cognitive and external contextualized process. In recent researches in Second Language Teacher Education, professional development or teacher learning encompasses knowing more about what language teachers know and do, and understanding more about how language teachers think and learn (Richards, 2008).

Many studies about previous language learning experiences (Bailey et al., 1996) and comparing experienced \& inexperienced language teachers (Tsui, 2003) indicate that experience is a key component of teacher development. Likewise, the studies from a technical view concern the symbiotic relationships between teachers' knowledge \& beliefs and classroom practice (Woods, 1996), but Golombek (1998) takes account of cognitive, affective \& emotional interacting factors in teaching practice. Additionally, some studies suggest that teachers' practices are influenced by social and environmental realities of school \& classroom (Richards \& Pennington, 1998). In China, there have been a few empirical studies related to EFL teachers' professional development in the past decade. Most of them take college EFL teachers as participants, but only Gu Peiya (2009) understands effective EFL teachers of primary \& secondary schools in view of cognitive learning and socio-cultural context, so it's necessary to continue similar researches about average secondary EFL teachers to promote English Language teaching in China.

On basis of Gu Peiya's model (Gu, 2009), four interrelated domains of professional development are brought into existence. They are learning experiences, knowledge \& beliefs, teaching practice and social context. As Schoonmaker (2002) states, experience is viewed as the sum of an individual's history, including actual events, fictionalized events and interpretations placed on them when they happened and as they are remembered. Therefore, research design firstly rests on learning experiences.

\section{Method}

\subsection{Research Design}

This research is qualitative, interpretative and exploratory in nature. Firstly it adopts deep interview for teachers' personal experiences. Thus a Pre-interview Inventory and an Interview Outline are drafted to seek progressive focuses. The Pre-interview Inventory includes eleven questions to list brief experiences, and then the Interview Outline covers some prompting questions with the aid of the Pre-interview Inventory. Thus not all the participants are asked identically in deep interview, but progressive focuses are sought according to narratives after instantaneous speculation.

Secondly, field notes are intended for data supplement and triangular verification. They involve the researcher's observation and thinking from her over-ten-year English teaching in secondary schools. Moreover, policy papers and related documents are found by official websites. Besides, the researcher takes notes of free talks and office visits in data collection. In fact, it gives an integrated perspective for data analysis.

\subsection{Participants}

By purposeful sampling, the participants are provided to have at least 10 years of teaching because such participants with rich experiences could massively show change and development in their career. On the other hand, gender, degree improvement, school transfer and honorary titles are considered as the dimensions of maximum variation to seek individual interpretations. As Table 1 shows, six secondary EFL teachers are engaged in deep interview, who distinguish themselves by years 1960s, 1970s \& 1980s and over 10 or 20 years of teaching. Generally speaking, they are called an experienced group, but not all of them are experts or proficient teachers.

\subsection{Data Collection and Analysis}

As described above, the right choice of methods and participants facilitated data collection. The Pre-interview Inventory was first given to the six participants in their free time for the benefit of more consideration and they returned inventories in a week. After careful review the researcher respectively fixed up one free afternoon to interview in their schools. All interviews were conducted in Chinese and recorded with MP4. Each took approximately one hour, but free talks continued after interview. These talks were not recorded due to research ethics but offered some valuable tips for data analysis.

Indeed, data analysis occurred during data collection and both were an ongoing process. Because all the data were complicated and particular, the researcher firstly underlined key words \& critical incidents and put them into various codes. Then these codes were classified into sub-categories and categories according to commonalities and discrepancies with the help of Gu Peiya (2009)'s coding scheme. As a matter of fact, the whole process of categorization was very difficult because these categories \& subcategories were intertwined in these teachers' professional development. 
Table 1. Participants' profile

\begin{tabular}{|c|c|c|c|c|c|c|c|}
\hline $\begin{array}{l}\text { Partici- } \\
\text { pants }\end{array}$ & $\begin{array}{l}\text { Years } \\
\text { born }\end{array}$ & Gender & $\begin{array}{l}\text { Years of } \\
\text { teaching }\end{array}$ & First degree & $\begin{array}{l}\text { Highest } \\
\text { degree }\end{array}$ & School transfer & $\begin{array}{l}\text { Honorary } \\
\text { titles }\end{array}$ \\
\hline \multirow{2}{*}{ Miss Y } & \multirow{2}{*}{1969} & \multirow{2}{*}{ Female } & \multirow{2}{*}{24} & \multirow{2}{*}{ Associate } & Under- & \multirow{2}{*}{$\begin{array}{l}\text { from town regular } \\
\text { to city key }\end{array}$} & PET \\
\hline & & & & & graduate & & MST \\
\hline Miss G & 1964 & Female & 29 & Associate & Associate & $\begin{array}{l}\text { from county key to } \\
\text { provincial key }\end{array}$ & \\
\hline Mr. W & 1972 & Male & 21 & $\begin{array}{l}\text { Under- } \\
\text { graduate }\end{array}$ & $\begin{array}{l}\text { Under- } \\
\text { graduate }\end{array}$ & $\begin{array}{l}\text { from city regular to } \\
\text { provincial key }\end{array}$ & PBT \\
\hline Miss $\mathrm{H}$ & 1976 & Female & 13 & Associate & $\begin{array}{l}\text { Post- } \\
\text { graduate }\end{array}$ & $\begin{array}{l}\text { from town regular } \\
\text { to city key }\end{array}$ & \\
\hline Mr. Z & 1980 & Male & 12 & $\begin{array}{l}\text { Under- } \\
\text { graduate }\end{array}$ & $\begin{array}{l}\text { Post- } \\
\text { graduate }\end{array}$ & city key(same) & \\
\hline Miss F & 1982 & Female & 10 & $\begin{array}{l}\text { Under- } \\
\text { graduate }\end{array}$ & $\begin{array}{l}\text { Under- } \\
\text { graduate }\end{array}$ & $\begin{array}{l}\text { Provincial } \\
\text { (same) }\end{array}$ & MET \\
\hline
\end{tabular}

Notes: Different honorary titles are awarded by different departments because of different aspects. PET (Provincial Excellent Teacher); MST (Municipal Star Teacher); PBT (Provincial Backbone Teacher); MET (Municipal Excellent Teacher).

\section{Results}

\subsection{Miss $Y$}

After graduation Miss Y continued to take part-time undergraduate courses for degree, i.e. national self-study exam of higher education. It is after she took the diploma that she had the chance of school transfer from town regular to city key. Then higher degree was a necessary advantage in Teacher Selection Test for Better-off Schools. Later she attended provincial backbone training, where she really realized that a teacher puts emphasis on the textbook while an educator focuses on whole-person growth. As the head of ELTR group, she made sharp contrasts in the ELTR activities between her two working schools. Most teachers in her previous school only received notices and had gossips while her present school includes mentorship, group preparation, open-class contests and so on. PBT and MST as she is, she still feels puzzled about the low English levels of her poor students who come from the rural area. Besides, she mentioned her junior English teacher's sweet voice and understood that students love English because of their love of the English teacher. She also stressed her personalized teaching styles as well as traditional knowledge-transmitted method at initial stage.

\subsection{Miss $G$}

Only Miss G is an exception due to the Cultural Revolution. She never studied English in the secondary period and worked as a shop assistant before NCEE. The most distinctive is her life philosophy that she disregards the power of leadership. It is sourced from an episode. She should have worked in a city-level shop because of her first place in then-job-test, but a relatively superior leader designated her daughter there. Thus she worked in a village-level shop. Owing to this, she decided to go to college by NCEE and began to study English by following Professor Chen on the radio. In fact, she often spares some time for listening in class, even though it was not tested in 1980s \& 1990s. What is impressive is that she was designated to teach some students who failed in NCEE several times as the only specialized English teacher. She felt proud and nervous, but she had no choice but to correct papers or prepare lessons into midnight. As a result, she got the first place in college admission rate in her county. In the successive years she kept the record. To a large degree, she was transferred from county key to provincial key, even though she had only an associate degree. In 2000 she took part in a provincial workshop for language competence, where she grasped the student-focused concept. Moreover, she loves students \& teaching by saying she is a born teacher and teaching is the sun-shining profession. 


\subsection{Mr. W}

Firstly, Mr. W received formal undergraduate degree and became an English teacher in a city regular school by virtue of State Job Assignment System. Secondly, great regional disparities in salaries \& benefits caused him somewhat burnout in teaching. With Labor Tide to the South, he went to a private school in Guangdong Province. All the teachers of core subjects participated in schooled-based technical study, which widely covered discussing routine teaching dilemmas, sharing Internet teaching resources and demonstrating courseware-making techniques. Thirdly, four years later he went back to his hometown and passed Teacher Selection Test for Better-off Schools. Thus he worked in his present provincial key school. Among these changes, his progressive computer skills are highlighted, partly acquired by his practical teaching and partly benefited from his private school. In 2012 he was selected as PBT and had a certain degree of job satisfaction.

\subsection{Miss $H$}

As the youngest child of her poor family, it is a great honor to go to college for the whole village because it meant a stable and promising job like an iron rice bowl. At graduation she was assigned to teach English in a distant town school. What embarrassed her most was not the poor physical surroundings but hidden extreme regionalism. That headmaster agreed that some teachers modified test scores for their townsmen to get more rewards. For another thing, town schools were popular with seriously deducting or suspending teachers' salaries until the start of $21^{\text {st }}$ century due to National Salary System. Thus she had to leave there and transferred herself to another town regular school. Encouraged by the fact that many teachers went for further study in this school, she made greater efforts to take full-time postgraduate education. Then she was recruited in the city key school as a postgraduate specialized in English. Obviously, she believes in linking theory with practice in teaching. She mentioned that she ever owed English learning failures to students' dullness while now she consciously provides the meta-cognitive strategies to develop learner autonomy.

\subsection{Mr. Z}

His family consists of four teachers, thus it is because of family faith that he becomes a teacher. At graduation he was employed to the city key school in 2002. As a new teacher, school administration department designated an experienced teacher as his mentor. He recalled that his mentor was really an excellent English teacher but was busy teaching first classes. Moreover, their lessons were arranged as similar in time. So he had to put himself into practical teaching and strived to adapt to curriculum reforms. Along with his skills with modern technology, he could solve most teaching problems. However, he complains that school evaluation overvalue qualifications and experiences. At present he's taking part-time postgraduate courses, which will be finished in 2016.

\subsection{Miss $F$}

At graduation Miss F met with several failures in job-hunting and National Civil-service Examination, which forced her to be a teacher in a provincial key school. In contrast, she is proud of her mentor, who gives her much impact on teaching ideas. Later their mentorship develops as friendship and fellowship. Especially when she got the first place in provincial teachers' basic skills competition, she had a sense of achievement and satisfaction. In 2013 she was honored as MET. To be honest, her brief experiences are described much more simply, because she is a quiet girl and is always working in the same school. In addition, she talked more about being a head-teacher, which is not the point of this research.

\section{Discussion}

\subsection{These Teachers Have Experienced Pre-service \& In-service and Formal \& Informal Learning that Has Different Features}

All these teachers received pre-service formal schooling including primary, secondary and college or university normal education, namely planned national education system. Apparently, English was their major and they strived for a threshold proficiency level in the target language as the qualification of EFL teachers. Truly, it provided them with rich knowledge and builds up a solid foundation for professional development. In contrast, pre-service informal learning is implied in critical incidents they mentioned unconsciously in free talks. It seems like the apprenticeship of observation (Freeman, 2002), which functions with power in various aspects.

Interestingly, these teachers with in-service formal training or further study think highly of such chances as milestones of life. However, such professional opportunities are relatively scarce like hanging up in the sky. Actually, it's really effective to renew specialized knowledge, expand teaching skills and promote educational concepts. Meanwhile, in-service informal learning at the workplace are typical of the following features. Firstly, uprising school transfer usually provides them with more learning opportunities from better-off environments. Next, realistic conflicts dedicate themselves to self-directed practical teaching because teaching is like the egg 
carton profession (Bailey et al., 2004). Thirdly, regular school-based group activities offer much space for effective teachers. However, it's not ready-made but situational owing to individual interpretations.

\subsection{These Teachers Hold some Common Knowledge \& Beliefs, Which Are always Developing but Fluctuate with Realities}

These teachers equal subject matter knowledge (Shulman, 1987) to language proficiency, which is evidenced by their certificates of CET-6 or TEM-8 in English at graduation. However, most of them recognize that their English competence at present are not higher than at graduation and even somewhat regress, though some keep learning English. Moreover, these teachers stress the development of students' language proficiency, but in a sense they have a strong belief in English as a tool for personal development.

For these teachers, pedagogical content knowledge (Richards, 1998) is teaching skills which make English comprehensible to students. In general, after at least a circular teaching they held basic teaching skills and comforted themselves in classroom teaching, i.e. professional survival. During a long period of teaching practice, they formed some personalized styles of teaching by observation, reflection and experimentation. However, they have new teaching puzzles in different transitions and may quickly find some insights or solutions from experiences. In a word, practical teaching helps them to master a repertoire of routine skills at their fingers.

Furthermore, these teachers believe that it is always basic for teachers to love students as parents love their children, but their loves to students are not equal, even if the same teacher at different stages. Likewise, they deem that the love to teaching as a career is a minimum for teachers, but such loves to teaching may fluctuate or change with practical teaching and realistic conflicts. Meanwhile, most of them think English teachers are the busiest and hardest group in secondary schools. Diverse teaching tasks increase mental stress but they have to pull themselves through every hardship by greater efforts than imagined.

4.3 These Teachers' Language Teaching Develops from Initial to Survival then to Mastery and Personalization, but Each Stage is Distinctive in Different Situations

At initial teaching these teachers adopted traditional knowledge-transmitted method by either borrowing their own learning methods or imitating their mentors' instructions. With increasing experiences from survival to personalized teaching, they enabled themselves to focus more on students and take students' need \& levels into overall consideration. Similarly, teaching resources is characterized as from inflexible to applicable. The teachers who taught in 1980s \&1990s only used textbooks, teachers' reference books and designated exercise books. In virtue of new national curriculum reform, newspaper, references books, test papers as well as Internet materials are listed in their daily resources. Nevertheless, they complain about too many exercises intended for NCEE as if students seemed like homework machines.

On the other hand, these teachers had to seek balance against realistic conflicts, which refer to new textbooks \& students' levels and teaching evaluation \& practical teaching. The disjunction between curriculum rhetoric and pedagogical reality has still existed especially in poor rural areas. It is beyond teachers' abilities \& efforts and needs support from the whole society. With regard to test scores as the first criteria of evaluation, these teachers enjoy themselves with honorary titles or desire it. All at once, they strongly sense the backwash effect of NCEE. However, test-scores is not the whole of teaching. They believe that English teaching could reach perfection of language, students, teachers and situations. As to salaries \& benefits as evaluation reward, it is closely related with National Salary System. Some unsatisfactory conditions, such as deduction or delay and regional inequity, makes them frustrated and exhausted in teaching practice.

\subsection{Social Context Facilitates or Constrains Their Professional Development, but Their Responses to it are Various to Seek Personal and Professional Balance}

Context is power and exerts its force everywhere. It either facilitates or constrains these teachers' professional development. For one thing, cooperative schools and favorable policies are noticeable in facilitating factors. According to Government Appraisals Rank System, most teachers' uprising school transfer mirrors great disparities in school administration and teacher cooperation. Besides, all the teachers share favorable policies, like State Assigned Job System in 1980s \&1990s and Teacher Selection Test for Better-off School together with New Recruit Regulations since the start of $21^{\text {st }}$ century. Such reforms convert socio-cultural values and provide positive context for these teachers.

However, these teachers can't get away from those unfavorable realistic conflicts as mentioned previously. They live with social values of self-discipline and obedience to authority in China, a highly centralized country. Therefore they have to receive frustrated realities and adapt themselves to harmony owing to individual efforts and aspiring desire. Meanwhile, narrow-minded decision making is at the school level. It is very unfortunate to 
work with such decision-makers but they struggle against it in school community through negotiation.

\section{Conclusions}

\subsection{Normal Education \& Professional Programs Play Essential Roles in Teacher Professional Development}

The combined model of normal education and language teaching provide these EFL teachers with rich knowledge about language and pedagogy, though it overvalues language communication skills while ignores language teaching skills. Moreover, national or provincial professional programs are too scarce in contrast to those regular staff-training activities. Actually, such professional programs are really effective for EFL teachers to expand teaching skills and renew educational concepts. In a word, normal education and formal programs play essential roles in professional development.

\subsection{Self-directed Teaching \& School-based Activities Provide Diverse Paths to Teacher Professional Development}

These EFL teachers firstly dedicate themselves to self-directed teaching and positively meet with teaching challenges in different situations. Such practical teaching leads to teaching expertise by observation, experimentation and reflection, but they have individual interpretations on basis of their unique backgrounds. Additionally, these teachers influence their colleagues or reverse through the ELTR group activities in intra-school but great disparities still exist in these activities, especially between city key and town regular. In a word, self-directed teaching and school-based activities provide diverse paths to professional development.

\subsection{Perfection of Language \& Teaching Serve as Special Professional Qualities of Teacher Professional Development}

These EFL teachers strive to develop their own language proficiency in various stages. As specialized competence, it is necessary for effective language teaching. Moreover, they emphasize the development of their students' language proficiency and hold beliefs about language in pragmatism. However, in current air of English learning \& teaching in China, these teachers hope to persistently pursue the perfection of language and teaching, which itself largely facilitate their professional development as EFL teachers' special professional qualities.

\subsection{Love for Students \& Love for Teaching Function as Original Driving Force of Teacher Professional Development}

These EFL teachers hold the minimum loves for students and teaching, which are often closely linked with each other. Both loves change or fluctuate with practical teaching and realistic conflicts. But such loves still ensure that they endeavor to develop student-oriented thinking and positively cope with teaching challenges. Moreover, they regard teaching \& education as their basic living pattern and primary life value. It provides original driving force to their professional growth especially when they feel frustrated with realistic conflicts.

\subsection{Chinese Social Context Works as Potential External Stimuli of Teacher Professional Development}

These EFL teachers can't get away from the whole Chinese social context they live in. To name only a few, the Cultural Revolution, National Salary System, New Curriculum Reforms. Either facilitating or constraining, whether these influences occur or not depends on situations in virtue of EFL teachers' internal world. That is to say, EFL teachers' individual efforts and aspiring desire from their internal world enable them to exploit favorable context and seek chances from unfavorable factors to navigate their professional development. Thus Chinese social context is regarded as potential external stimuli which exert its formative effect in professional development.

\section{Suggestions}

\subsection{Suggestions to Educational Administrators, Teacher Educators and EFL Teachers}

For educational administrators, they should successively formulate an integrated system of teacher education by regulating course structure \& contents of pre-service education and drafting systematized in-service training plans. Secondly, they should create communities of practice for teacher cooperation by supporting school-based ELTR activities, especially about practical teaching dilemmas, teacher research and technological teaching skills. Furthermore, they keep open-minded to build harmonious atmosphere by EFL teachers' mutual participation in school administration \& construction.

For teacher educators, they need to incorporate cognitive and affective development into the improvement of language proficiency and teaching skills in program design and course activities. Besides, they should encourage prospective or practicing EFL teachers to recollect and share their life stories or classroom incidents. Thus these EFL teachers could develop their capacities of self-directed teaching through critical reflection, which is 
significant for their professional development.

For EFL teachers, they should unceasingly promote professional qualities and renew pedagogical concepts. Also, they actively take part in school-based interactive activities and professional training programs. In fact, they should keep aspiring desire of teaching expertise and high awareness of professional growth in mind. In addition, they should continue to develop their understanding of their work contexts, from which they could seek any opportunities of teacher learning and professional development.

\subsection{Suggestions to Further Research}

In this research, the participants are six experienced secondary EFL teachers in contrast to the large population of Chinese EFL teachers. So if more different levels of EFL teachers participate in it, these results, discussions and conclusions will be more appreciated and convincing. Therefore, similar studies should be designed to include a larger and more diverse group of EFL teachers.

Moreover, general questionnaire should be more comprehensive to investigate change and development. So research methodologies should be broadened and optimized in the future. Besides, the new light of teacher learning should be widely accepted in the studies of professional development in the field of foreign language teaching.

\section{References}

Bailey, K., \& Nunan, D. (Eds.). (1996). Voices from the Language Classroom: Qualitative Research in Second Language Education. Cambridge: Cambridge University Press.

Bailey, K. M., Curtis, A., \& Nunan, D. (Eds.). (2004). Pursuing Professional Development: The Self as Source. Beijing: Foreign Language Teaching and Research Press.

Freeman, D. (2002). The hidden side of the work: Teacher knowledge and learning to teach. Language Teaching, 35, 1-13. http://dx.doi.org/10.1017/S0261444801001720

Fullan, M \& Stiegelbauer, S. (Eds.) (1991). The New Meaning of Educational Change (2nd ed.) New York: Teachers College Press.

Golombek, P. R. (1998). A study of language teacher's personal practical knowledge. TESOL Quarterly, 32, 447-464. https://doi.org/10.2307/3588117

Gu Peiya. (Ed.). (2009). Understanding EFL Teachers as Learners: Case Studies. Beijing: Foreign Language Teaching and Research Press.

Ministry of Education of the People's Republic of China. (2012). National English curriculum standards for compulsory education. Beijing: Beijing Normal University.

Nunan, D. (2003). The impact of English as a global language on educational policies and practices in the Asia-Pacific region. TESOL Quarterly, 37, 589-613. https://doi.org/10.2307/3588214

Richards, J. C. (Ed.) (1998). Beyond Training. Cambridge: Cambridge University Press, 1998.

Richards, J. C., \& Pennington, M. (1998). The first year of teaching. In J. C. Richards (Ed.), Beyond Training (pp. 173-200). Cambridge: Cambridge University Press.

Richards, J. C. (2008). Second language teacher education today. RELC Journal, 39, 158-177. http://dx.doi.org/10.1177/0033688208092182

Schoonmaker, F. (Ed.) (2002). “Growing up” Teaching: From Personal Knowledge to Professional Practice. New York: Teachers College Press.

Shulman, L. S. (1987). Knowledge and teaching: Foundations of new reform. Harvard Educational Review, 57 , 1-22. https://doi.org/10.17763/haer.57.1.j463w79r56455411

Tsui, A. B. M. (Ed.). (2003). Understanding Expertise in Teaching: Case Studies of Second Language Teachers. New York: Cambridge University Press. https://doi.org/10.1017/CBO9781139524698

Woods, D. (Ed.). (1996). Teacher Cognition in Language Teaching. Cambridge: Cambridge University Press.

\section{Notes}

Note 1. In China, many teachers work in a school and then are transferred into another school. Even a small part of them transfer themselves into a third or fourth school. Owing to the Chinese-styled system of school evaluation, primary and secondary schools are usually divided into provincial key schools, city key schools, city 
regular schools and town regular schools. Their differences lie in whether the schools have better facilities, more qualified staff and more capable students or not.

Note 2. In the latter part of the $20^{\text {th }}$ century, most of the pre-service teachers were arranged to work in different schools at the command of State Job Assignment System and got their own salaries according to National Salary System. But this salary system had some deficiencies, such as regional disparity and deduction or delay. Since 1990s, the economic opening-up policy in China has attracted many people including teachers to work in those first-developed coastal cities in the south of China. This is just like the tide into the sea, which is called Labor Tide to the South. Nowadays, one typical system for human resources is National Civil-service Examination, through which people can work in government sectors, state-owned enterprises and public institutions. And another system Teacher Selection Test for Better-off Schools is intended for teachers for school transfer.

\section{Copyrights}

Copyright for this article is retained by the author(s), with first publication rights granted to the journal.

This is an open-access article distributed under the terms and conditions of the Creative Commons Attribution license (http://creativecommons.org/licenses/by/4.0/). 